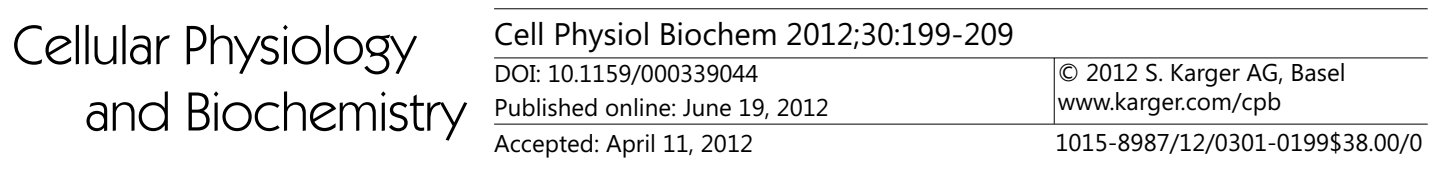

\title{
Impact of oxLDL and LPS on C-type Natriuretic Peptide System is Different between THP-1 Cells and Human Peripheral Blood Monocytic Cells
}

\author{
Martin Bruckmeier* Andreas Kuehnl* Mihaela Culmes Jaroslav Pelisek \\ Hans-Henning Eckstein \\ Clinic for Vascular and Endovascular Surgery, Klinikum rechts der Isar, Technische Universität München \\ *Both authors contributed equally to this work
}

\author{
Key Words \\ C-type natriuretic peptide $\cdot$ Monocytes $\cdot$ THP-1 cells $\cdot$ Atherosclerosis $\bullet$ Gene expression
}

\begin{abstract}
Background: The C-type natriuretic peptide (CNP) has anti-inflammatory, anti-proliferative, and anti-migratory properties. The purpose of this study was to investigate the occurrence of CNP and its receptors (NPR2 and NPR3) in a human monocytic cell line (THP-1 cells) as well as in peripheral blood monocytic cells (PBMC). Impact of both, LPS and human oxLDL on expression pattern of CNP and its receptors shall be studied. Methods: Cells were cultured in standard medium with or without LPS or oxLDL. Expression levels of CNP, NPR2, NPR3, TNF$\alpha$, IL-1 $\beta$, IL-6, CD14 and CD68 were measured at baseline, 24h, and 48h. Results: Baseline expression of all analysed genes was significantly higher in PBMC compared to THP-1 cells (all $\mathrm{p}<0.05)$. Expression levels of CNP, IL- $1 \beta$, IL- 6 , and CD14 were significantly increased in PBMC following stimulation with LPS. In contrast, in THP-1 cells stimulated by LPS, significant increase in expression was found only for IL- $6(p=0.007)$. In THP- 1 cells, oxLDL increased the expression levels of NPR3, TNF- $\alpha$, IL-1 $\beta$, IL-6, CD14, and CD68 significantly. In contrast, expression level of NPR2 was diminished by oxLDL $(p=0.007)$. In PBMC NPR3 was significantly down-regulated $(p=0.002)$. Treatment with oxLDL for $48 \mathrm{~h}$ increased NPR2/3-ratio significantly in PBMC (22.5 vs. $4.8, \mathrm{p}=0.010$ ). In contrast, in THP-1 cells, NPR2/3-ratio was lowered significantly by oxLDL (0.31 vs. 17.0, $p=0.008)$. Conclusion: Treatment with LPS or oxLDL leads to diverging changes in gene expression PBMC and THP-1 cells. With respect to CNP and its receptors, data gained from THP-1 cells should be further validated using naive human peripheral blood monocytes. However, THP-1 cells can serve as a negative control for e.g. future signalling pathway studies related to oxLDL effect on CNP system in monocytes/macrophages.
\end{abstract}




\section{Cellular Physiology $\quad$ Cell Physiol Biochem 2012;30:199-209

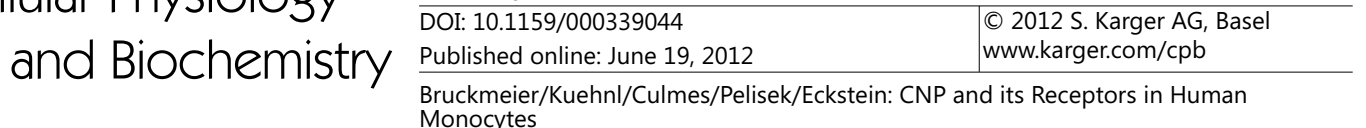

\section{Introduction}

Atherosclerosis related diseases are leading causes of death in the western world [1]. Plaque formation is a consequence of lipid accumulation in the sub-endothelial space, LDL oxidation by ROS, endothelial dysfunction, inflammation, foam cell formation, necrosis, and fibrosis [2]. Major players in this chain of events are monocytes and macrophages invading into thevesselwall[3]. Monocytes and macrophages incorporate oxidized low-densitylipoproteins (oxLDL) mediated by scavenger receptors. It was shown, that oxLDL leads to an activation of proteinkinase C (PKC), PI3-kinase, cyclooxygenase-2, and the MAP kinase pathway [4]. These biological processes stimulate in turn macrophages to secrete a plethora of cytokines like TNF- $\alpha$, interleukins, interferons, enzymes and growth-factors [3]. Together with cytokines released by activated T-cells, the latter factors promote inflammation, proliferation of smooth muscle cells, dysfunction of the endothelium, and consecutively plaque formation $[3,5]$.

During the past years, CNP has aroused increasing interest in the researchers of cardio-vascular related diseases [6-8]. CNP, which was identified 1990 by Sudoh et al. [9] is the most ancient member of the natriuretic peptide family [10]. CNP inhibit neointimal restenosis [11], reduces vascular constrictive remodelling [12], oxidative stress[13], and cardiac ischemia-reperfusion injury [14]. CNP plays an important role in bone growth [15, 16], reproduction [17, 18], nerve growth [19], re-endothelialisation [20], as well as renal [21], pancreatic [22], and cardiac function [23]. In addition, CNP has anti-proliferative and anti-migratory properties $[11,24,25]$ and was also identified as an endothelium derived relaxing factor [26-28]. CNP stimulates selectively the human natriuretic peptide receptor 2 (NPR2), which in turn activates the cGMP-dependent kinase (cGK) by elevating intracellular level of cGMP [14]. In addition, CNP binds NPR3 that deactivates protein kinase A by $\mathrm{G}_{\mathrm{i}}$-protein dependent inhibition of adenylatcyclase [29]. It was shown, that C-type natriuretic peptide (CNP) is able to inhibit activation of cyclooxygenase-2 [30], MAP kinase as well as activation of PI3-kinase [31]. CNP decreases also activity of PKC via activation of natriuretic peptide receptor 2 (NPR2) [29]. In contrast, activation of NPR3 leads to activation of PKC via activation of phospholipase $C$ [29]. These findings suggest that the expression ratio of NPR-2 and NPR-3 on the cell surface might be associated with the sensitivity of monocyte cells to stimulation with LPS and oxLDL. PKC activation, i.e. by pressor hormons or oxLDL have been shown to act as negative feedback and lead to desensitization of natriuretic peptide induces cGMP accumulation [32]. Therefore, the purpose of this study was to investigate the impact of human oxLDL on expression pattern of CNP and its receptors in human peripheral blood monocytic cells (PBMC) as well as in a stable human monocytic cell line (THP-1 cells).

THP-1 cells have become one of the most widely used cell lines to investigate the function an regulation of monocytes and macrophages in the cardiovascular system [33, 34]. THP-1 cells have some advantages over human primary monocytes-macrophages like a homogenous genetic background, higher storage stability and better suitability for gene transfection[34]. However, in consideration of its leukemia trait, it is necessary to determine the extent to which THP- 1 cells mimic naïve monocytes and macrophages [34]. Published evidence regarding this question was recently reviewed by Qin et al. [34].

With respect to CNP and its receptors it is still not clear yet, how far the results from experiments using THP-1 cells are comparable to the physiological function of primary human monocytes. For this reason, we analysed basic expression rates of CNP, NPR-2, NPR-3, TNF- $\alpha$, IL-6, IL-1b, CD 14 and CD 68 in THP-1 cells and compared these results with the expression of the same genes in PBMC. Both cell types were stimulated with LPS and oxLDL to follow the changes in the above mentioned basic gene expression profile. 


\section{Cellular Physiology $\quad$ Cell Physiol Biochem 2012;30:199-209 \begin{tabular}{ll|l} 
and Biochemistry & $\begin{array}{l}\text { DOI: 10.1159/000339044 } \\
\text { Published online: June 19, } 2012\end{array}$ & $\begin{array}{l}\text { () 2012 S. Karger AG, Basel } \\
\text { www.karger.com/cpb }\end{array}$ \\
\cline { 2 - 2 }
\end{tabular} Bruckmeier/Kuehnl/Culmes/Pelisek/Eckstein: CNP and its Receptors in Human Monocytes}

\section{Materials and Methods}

RPMI-1640, fetal bovine serum (FBS), penicillin/streptomycin (Pen/Strep), L-glutamine, HEPES and tissue culture plastics were obtained from PAA (Cölbe, Germany). LPS, suitable for cell culture use, was provided by Sigma-Aldrich, Taufkirchen, Germany. LPS was extracted from Escherichia coli 0111:B4, purified by gel filtration chromatography and gamma radiated for sterilisation. Oxidized LDL (oxLDL) was provided by Biomedical Technologies, Stoughton, USA (\#BT-910X Human Ox-LDL, Hi TBAR). Human LDL was purified to homogeneity via ultra-centrifugation and oxidised using $3.5 \mu \mathrm{M} \mathrm{CuSO}_{4}$ in $\mathrm{PBS}$ at $37^{\circ} \mathrm{C}$ for 24 hours. Oxidation process was terminated by adding excess EDTA and analysed by agarose gel electrophoresis for migration versus LDL (oxLDL migrates 2.7 fold further than the native LDL). The product was then membrane filtered, aseptically packaged, and had no detectable endotoxin level. OxLDL was used within one week following shipment. All other chemical compounds were purchased from Sigma-Aldrich if not mentioned other.

\section{Blood collection and cell isolation}

Peripheral blood samples were drawn separately from three healthy volunteers (male, median age 33) using standard blood collection tubes $\left(\mathrm{NH}_{4}\right.$-Heparinat Monovette, Sarstedt, Germany). Peripheral mononuclear cells were obtained by density gradient centrifugation using Histopaque-1077 (Sigma Aldrich Chemie $\mathrm{GmbH}$, Steinheim, Germany) in Leucosep ${ }^{\mathrm{TM}}$ tubes (Greiner Bio-One, Frickenhausen, Germany). According to the manufacturer instructions, peripheral blood was diluted with phosphate buffered saline, PBS, PH 7.4 (Sigma-Aldrich, Taufkirchen, Germany) in a dilution ratio of 1:1. After centrifugation, plasma was collected and saved for later use. Buffy coat containing PBMCs was harvested and washed twice with PBS. Cells were cultivated in RMPI-1640 supplemented with 1\% L-Glutamin, 2\% HEPES, 1\% Pen/Strep culture medium, including 10\% autologous human plasma. After 12 hours supernatant was discarded and adherent cells were gently removed from the surface, washed with PBS and used for further experiments. Yield of CD14+-cells and CD16 $6^{+}$-cells was analyzed by FACS Canto II (BD Biosciences, San Jose, CA, USA) using anti-CD14 and anti-CD16 (BD Biosciences Pharminge, San Diego, CA, USA). Human THP1-monocytes were obtained from own cell culture depot (ATCC® TIB202, LGC Standards GmbH, Germany) and cultured according to established recommendations [33].

\section{Cell culture model}

Monocytes were cultured under standardized conditions, using standard culture medium (RMPI1640, 1\% L-Glutamin, 2\% HEPES, 10\% autologous plasma, 1\% pen/strep). Cells were cultured in 6well-plates, containing an amount of 750.000 cells per well. THP-1 monocytes were cultured according to recommendations in RPMI-1640 Medium supplemented with 10\% FBS, 1\% L-glutamine, 1\% Pen/ Strep [33]. THP-1 monocytes were also cultured in 6-well-plates, containing an amount of 500.000 cells per well. Total mRNA of human monocytes and THP-1 cells was extracted immediately after isolation of the cells as well as after $24 \mathrm{~h}$ and after $48 \mathrm{~h}$ of cultivation in standard medium. Concomitantly, both cell types were stimulated for $24 \mathrm{~h}$ with $0.05 \mu \mathrm{g} / \mathrm{ml}$ LPS. Finally, monocytes and THP-1 cells were stimulated for 48 hours with $50 \mu \mathrm{g} / \mathrm{ml}$ of human oxidized low density lipoproteins (oxLDL) added to standard medium. Concentration of LPS and oxLDL as well as measurement time points were set according to previous optimization experiments (data not shown) and literature review [30, 35-40].

\section{RNA Isolation and cDNA Synthesis}

Total RNA from monocytes and THP-1 cells was isolated from cell lysates by using peqGOLD total RNA Kit (PeqLab Biotechnologie GmbH, Erlangen, Germany) with an additional step of DNA digestion with DNase I (Quiagen, Hilden, Germany). cDNA was synthesized using the RevertAid ${ }^{\mathrm{TM}}$ Premium First Strand cDNA Synthesis Kit (Fermentas, St. Leon-Rot, Germany) according to the manufacturer instructions.

\section{Quantitative real-time PCR}

Expression level of CNP, NPR-2, NPR-3, TNF- $\alpha$, IL-6, IL-1 $\beta$, CD14, and CD68 were assessed by quantitative real-time PCR (QuantiFast ${ }^{\mathrm{TM}}$ SYBR Green, Qiagen) using specific oligonucleotide primers (QuantiTect Primer Assay, Qiagen). All quantitative PCR reactions were performed with an iCycler $\mathrm{iQ}^{\mathrm{TM}}$ (BioRad, Munich, Germany) using the following conditions: $10 \mathrm{~s}$ at $95^{\circ} \mathrm{C}, 30 \mathrm{~s}$ at $60^{\circ} \mathrm{C}$, and $10 \mathrm{~s}$ at $72^{\circ} \mathrm{C}$ for 45 cycles. All expression levels were normalized to expression of the house-keeping gene GAPDH. 


\section{Cellular Physiology Cell Physiol Biochem 2012;30:199-209 \\ and BiOChemistry \begin{tabular}{l|l} 
DOI: 10.1159/000339044 & $\begin{array}{l}\text { Published online: June 19, 2012 S. Karger AG, Basel } \\
\text { www.karger.com/cpb }\end{array}$ \\
$\begin{array}{l}\text { Bruckmeier/Kuehnl/Culmes/Pelisek/Eckstein: CNP and its Receptors in Human } \\
\text { Monocytes }\end{array}$
\end{tabular}}

Table. Comparison of expression levels between PBMC and THP-1 cells. Expression levels are normalized to GAPDH. All genes were significantly higher expressed in human monocytes.

\begin{tabular}{lllcl}
\hline \multicolumn{5}{c}{ expression level at baseline (0h) } \\
Gene & PCMO & THP-1 & PCMO/THP-1 & p-value \\
\hline CNP & $1.468 \times 10^{-2}$ & $1.800 \times 10^{-4}$ & 82 & $<0.001$ \\
NPR2 & $5.843 \times 10^{-3}$ & $6.203 \times 10^{-5}$ & 94 & $<0.001$ \\
NPR3 & $7.811 \times 10^{-4}$ & $1.176 \times 10^{-6}$ & 664 & $<0.001$ \\
TNF- $\alpha$ & $8.607 \times 10^{-2}$ & $1.638 \times 10^{-2}$ & 5 & 0.003 \\
IL-1 $\beta$ & $1.329 \times 10^{-1}$ & $8.363 \times 10^{-4}$ & 159 & $<0.001$ \\
IL-6 & $1.141 \times 10^{-3}$ & $4.875 \times 10^{-6}$ & 234 & $<0.001$ \\
CD14 & 1.663 & $3.808 \times 10^{-4}$ & 4368 & $<0.001$ \\
CD68 & 3.060 & $1.393 \times 10^{-2}$ & 220 & $<0.001$ \\
\hline
\end{tabular}

Table 2. Effect of LPS and oxLDL expressed as ratio between gene expression levels following treatment compared to cultivation in standard medium. Expression levels are normalized to GAPDH. See also Fig. 1 and 2. Significant results are marked with asterisks (*).

\begin{tabular}{lllll}
\hline & \multicolumn{2}{l}{ changes by LPS (24h) } & \multicolumn{2}{l}{ changes by 0 oxLL (48h) } \\
Gene & PCM0 & THP-1 & PCM0 & THP-1 \\
\hline CNP & $17.7^{*}$ & 1.66 & 0.37 & 1.52 \\
& $\mathrm{p}=0.045$ & $\mathrm{p}=0.840$ & $\mathrm{p}=0.207$ & $\mathrm{p}=0.057$ \\
NPR2 & 2.20 & 1.86 & 0.86 & $0.26^{*}$ \\
& $\mathrm{p}=0.167$ & $\mathrm{p}=0.486$ & $\mathrm{p}=0.700$ & $\mathrm{p}=0.007$ \\
NPR3 & 1.61 & 1.24 & $0.20^{*}$ & $16.9^{*}$ \\
& $\mathrm{p}=0.116$ & $\mathrm{p}=0.686$ & $\mathrm{p}=0.002$ & $\mathrm{p}=0.023$ \\
TNF- $\alpha$ & 3.84 & 0.92 & 0.67 & $8.66^{*}$ \\
& $\mathrm{p}=0.209$ & $\mathrm{p}=0.343$ & $\mathrm{p}=0.350$ & $\mathrm{p}=0.007$ \\
IL-13 & $31.8^{*}$ & 0.79 & 0.57 & $68.3^{*}$ \\
& $\mathrm{p}<0.001$ & $\mathrm{p}=0.886$ & $\mathrm{p}=0.056$ & $\mathrm{p}=0.007$ \\
IL-6 & $1718^{*}$ & $12.0^{*}$ & 0.37 & $113^{*}$ \\
& $\mathrm{p}<0.001$ & $\mathrm{p}=0.007$ & $\mathrm{p}=0.084$ & $\mathrm{p}=0.007$ \\
CD14 & $41.0^{*}$ & 2.31 & 0.52 & $29.3^{*}$ \\
& $\mathrm{p}=0.006$ & $\mathrm{p}=0.232$ & $\mathrm{p}=0.160$ & $\mathrm{p}=0.007$ \\
CD68 & 3.77 & 0.64 & 0.87 & $4.38^{*}$ \\
& $\mathrm{p}=0.454$ & $\mathrm{p}=0.343$ & $\mathrm{p}=0.876$ & $\mathrm{p}=0.010$ \\
\hline & & & &
\end{tabular}

Statistics

Data are shown as means \pm standard error of the mean (SEM). To compare the means of two independent samples, robust Mann-Whitney-U Test was applied. For comparison between more than two groups, Kruskal-Wallis test was used. 95\% confidence intervals of NPR2/3-ratio was calculated according to Rinne [41]. Statistical significance was assumed at p-values $<0.05$. Data were analyzed using MedCalc® for Windows, Version 10.0.1.0 (MedCalc Software, Mariakerke, Belgium).

\section{Results}

Yield of CD14+-cells and CD16 ${ }^{+}$-cells in the fraction of human PBMC was $73.1 \%$ and $14.6 \%$, respectively. Expression levels at baseline, 24h, and $48 \mathrm{~h}$ are shown in figure 1 and figure 2 (black columns and dark green columns). As listed in Table 1, all genes were significantly higher expressed (5-4368 times) in PBMC than in THP-1 cells (exact values are listed in Table 1). As shown in Table 2, expression levels of CNP, IL-1 $\beta$, IL-6, and CD14 were significantly increased in PBMC following stimulation with LPS. In contrast, in THP-1 cells stimulated by LPS, significant increase in expression was found only for IL-6 ( $p=0.007)$.

Treatment with oxLDL slightly diminished expression levels of all genes in PBMC. However, this down-regulation was statistically significant only for NPR3 ( $p=0.002)$. In THP1 cells, oxLDL increased the expression levels of NPR3, TNF- $\alpha$, IL-1 $\beta$, IL-6, CD14, and CD68 significantly (see Table 2). In contrast, expression level of NPR2 was diminished by oxLDL $(\mathrm{p}=0.007)$. Impact of LPS and oxLDL on PBMC and THP-1 cells are visualized in Fig. 1 and Fig. 2. 


\section{Cellular Physiology $\quad$ Cell Physiol Biochem 2012;30:199-209

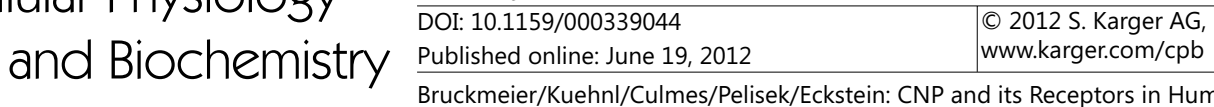 Bruckmeier/Kue
Monocytes}

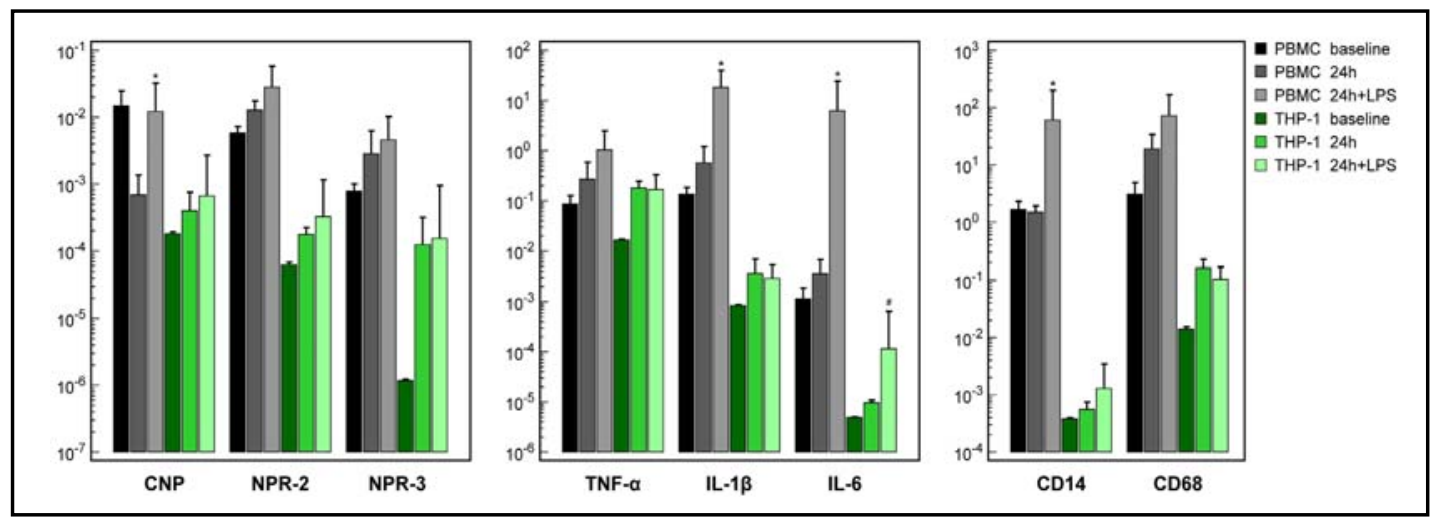

Fig. 1. Impact of LPS on gene expression (normalized to GAPDH expression, means \pm SEM). PBMC=human peripheral blood monocytic cells, THP=THP-1 cell line, LPS $=0.05 \mu \mathrm{g} / \mu \mathrm{l}$ lipopolysaccharide, ${ }^{*}=\mathrm{p}<0.05$ compared to PBMC $24 \mathrm{~h}, \#=\mathrm{p}<0.05$ compared to THP $24 \mathrm{~h}$.
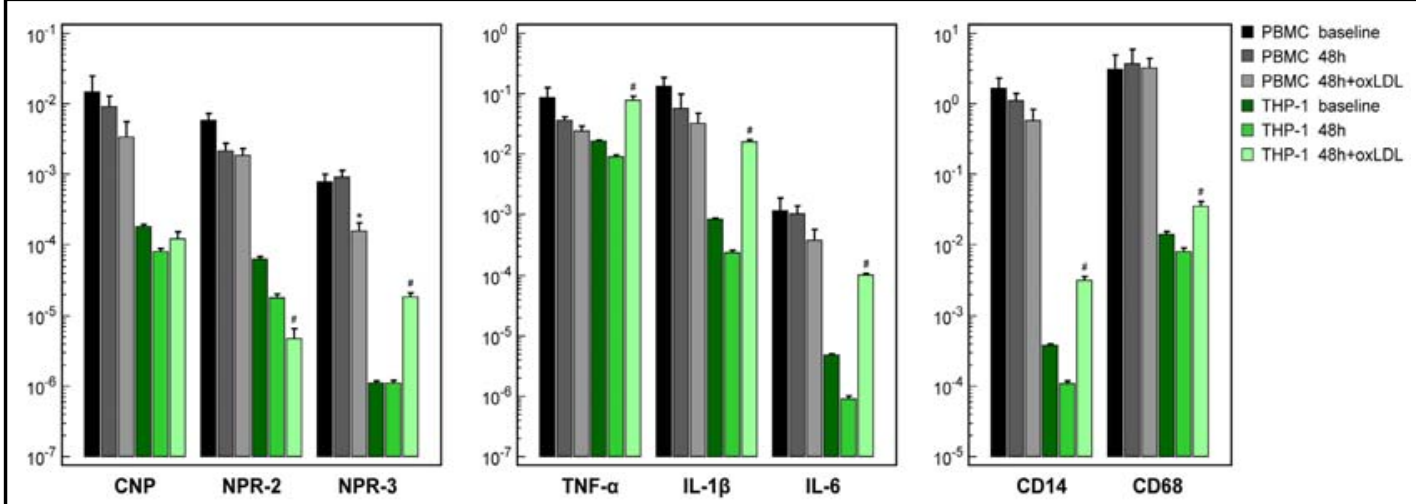

Fig. 2. Impact of oxLDL on gene expression (normalized to GAPDH expression, means \pm SEM). PBMC=human peripheral blood monocytic cells, THP=THP-1 cell line, oxLDL=50 $\mu \mathrm{g} / \mathrm{ml}$ human oxidized $\mathrm{LDL},{ }^{*}=\mathrm{p}<0.05$ compared to PBMC 48h, \#=p<0.05 compared to THP 48h.

Fig. 3. NPR2/3-ratio (mean with $95 \%$ confidence interval) in human PBMC (black lines) and THP-1 cells (green lines).

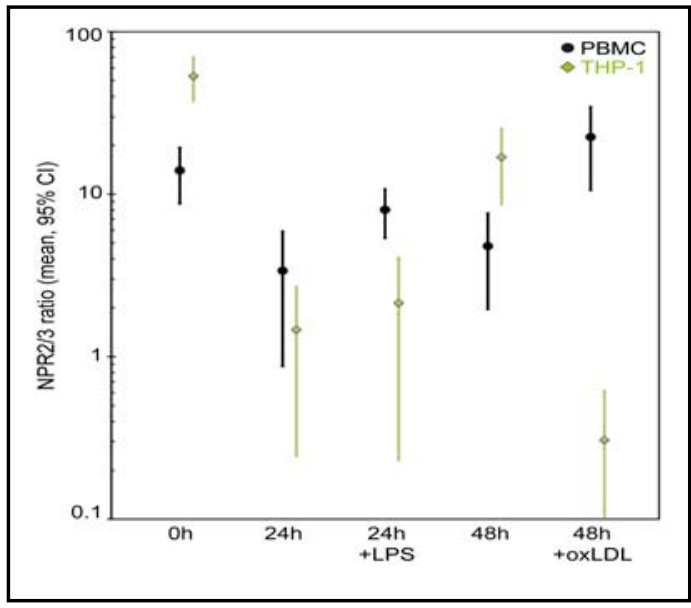

As shown in Fig. 3, NPR2/3-ratio was significantly higher in THP-1 cells at baseline and after $48 \mathrm{~h}$ (53.6 vs. 14.0, $\mathrm{p}=0.001$ ). Within cell lines, LPS showed no impact on NPR2/3ratio, but has a significant effect on NPR2/3-ratio when comparing PBMC and THP-1 (8.1 vs. $2.1, \mathrm{p}=0.001$ ). Treatment with oxLDL for $48 \mathrm{~h}$ increased NPR2/3-ratio significantly in PBMC (22.5 vs. $4.8, \mathrm{p}=0.010$ ). In contrast, oxLDL decreased NPR2/3-ratio significantly in THP-1 cells (0.31 vs. $17.0, \mathrm{p}=0.008)$. 


\section{Cellular Physiology Cell Physiol Biochem 2012;30:199-209 \\ \begin{tabular}{ll|l} 
and BiOChemistry & $\begin{array}{l}\text { DOI: 10.1159/000339044 } \\
\text { Published online: June 19, } 2012\end{array}$ & $\begin{array}{l}\text { C 2012 S. Karger AG, Basel } \\
\text { www.karger.com/cpb }\end{array}$ \\
\cline { 2 - 3 } Bruckmeier/Kuehnl/Culmes/Pelisek/Eckstein: CNP and its Receptors in Human
\end{tabular} \\ Bruckmeier/Kuehnl/Culmes/Pelisek/Eckstein: CNP and its Receptors in Human
Monocytes}

\section{Discussion}

The present study shows for the first time that expression of CNP and its receptors are regulated by oxLDL in human monocytes and that this effect is different between THP-1 cells and PBMC. THP-1 cells are widely used for studying a large variety of pathophysiologic functions in human monocytes [34]. Furthermore, THP-1 cells are also used to study hypotheses and mechanisms of atherosclerosis [42-44]. As comprehensively reviewed by Qin et al. [34], THP-1 cells are suitable for the study of the novel functions and mechanisms in monocytes-macrophages in the cardiovascular system, but it is also important to recognize that THP-1 cells and primary monocytes-macrophages have significant differences [34]. With respect to CNP and its receptors, the present study hints that THP-1 cells and PBMC might not be comparable.

In this study, the average purity of human PBMC ranged from $70.3 \%$ up to $75.5 \%$. These findings are in line with previous published purity rages (64-98\%) [45-47]. The isolation of monocytes by density gradient centrifugation is a well established and rather inexpensive method compared to their isolation by e.g. magnetic beads. This method leads to a higher purity of isolated monocytes [46]. Unfortunately, the magnetic bead complexes often cannot be removed from isolated monocytes, which may cause interference with the analysis of cell surface markers.

At baseline expression levels of all analysed genes were significantly higher in human PBMC than in THP- 1 cells. This difference might be mainly due to the fact that THP- 1 cells are different types of monocytes, originating from acute monocytic leukemia cells [33]. This issue is extensively discussed by Qin et al. [34] as well.

\section{Effect of oxLDL and LPS on CNP and its receptors}

With respect to oxLDL, only one study [48] analysed the effect of oxLDL on secretion of CNP, so far. This study was carried out in bovine endothelial cells. Furthermore, expression levels of NPR2 and NPR3 have not yet been determined. It was shown, that oxLDL $(50 \mu \mathrm{g} / \mathrm{ml})$ reduces secretion level of CNP by $31 \%$ after 24 hours. In our study oxLDL leads also to reduced expression levels of CNP. As shown in Fig. 2 and Table 2, this reduction was 63\% after 48h.

Midyear 2011, Sellitti et al. reviewed the current literature on the regulation of CNP expression [49]. They identified two studies concerning regulation of expression level of CNP by LPS. The first study [50] revealed that LPS increases CNP mRNA level up to 300fold in mouse macrophages. The second study [51] showed a mutually inconsistent stimulating effect of LPS on CNP secretion in two macrophage cell lines (THP-1 and HL-60). In addition, no effect of LPS was found in human monocytes/macrophages [51]. Although cell culture setting (cell types, isolation of PBMC, and stimulation by LPS $0.1 \mu \mathrm{g}$ / $\mathrm{ml}$ ) was comparable to our experiments, outcome measurement was markedly different (cumulative secretion of CNP peptide after 40h vs. expression level of CNP-mRNA after 24h).

Review of the literature identified two additional studies [52,53] concerning the effect of LPS on CNP expression/secretion. The first study shows that LPS induces CNP secretion in bovine endothelial cells [52]. The second study revealed that expression of CNP is increased in the hypothalamus of rats after induction of septic shock using LPS [53].

In summary, to our knowledge, the present study shows for the first time that expression of CNP and its receptors are regulated by oxLDL in human monocytes and that this effect is different between THP-1 cells and PBMC. So far, impact of LPS on expression of CNP has been shown in four other studies. Due to methodological issues results are not comparable directly. However, influence of LPS on NPR2 and NPR3 was analysed only in our study.

Effect of LPS on inflammatory cytokine expression

Stimulation of PBMC with LPS leads to an upregulation of inflammatory proteins like TNF- $\alpha$, IL-1 $\beta$, and IL-6. In addition, expression of LPS receptor CD14 and macrophage marker CD68 was upregulated by LPS. These findings are in accordance with other reports 


\section{Cellular Physiology $\quad$ Cell Physiol Biochem 2012;30:199-209

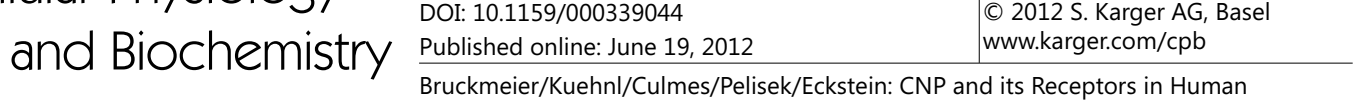 \\ Bruckmeier/Kuehnl/Culmes/Pelisek/Eckstein: CNP and its Receptors in Human
Monocytes}

[30]. In contrast, stimulation of THP-1 cells with LPS leads to upregulation only of IL-6. This may be due to possible earlier increase of inflammation in THP-1 cells and thus, to an earlier decay. Therefore, different results in PCMO and THP- 1 may be caused also by dissimilar time-course of inflammatory response. In accordance to our study LPS induced higher expression levels of inflammatory markers TNF- $\alpha$, IL-1 $\beta$, and IL- 6 in PBMC in several other studies [54-58]. Isolation of PBMC, culture conditions, LPS concentrations $(0.01-1 \mu \mathrm{g} / \mathrm{ml})$, and measurement time points $(6-48 \mathrm{~h})$ were approximately comparable to the present study as well. In THP-1 cells, effect of LPS was analysed amongst others by Perez-Perez and co-workers [59]. In accordance to our study (LPS concentration 0.05 $\mu \mathrm{g} /$ $\mathrm{ml}$ ), increase of TNF- $\alpha$ was observed not before LPS concentration was higher than $50 \mu \mathrm{g} /$ $\mathrm{ml}$. This issue was explained by the fact that LPS signal-transduction is augmented by LPS binding protein (LBP). PBMC culture medium contains $10 \%$ autologous serum, while THP-1 culture medium contains 10\% FCS. However, expression of IL- 6 was significantly increased by LPS in THP- 1 cells as well. In addition, difference of LPS effects between PCMO and THP-1 cells might also be due to the more than 4000-fold higher expression level of LPS receptor (CD14) in PCMO. Bas et al. showed that LPS stimulation of THP-1 cells leads to significant higher levels of TNF- $\alpha$, IL-1 $\beta$, and IL-6 [54]. In contrast to our study, LPS concentration was however 20 times higher, LPS was derived from different serotype, and measurement of inflammatory markers was carried out cumulatively by ELISA after $48 \mathrm{~h}$.

\section{Effect of oxLDL on inflammatory cytokine expression}

Except of NPR2, expression level of all analysed genes were up-regulated by oxLDL after $48 \mathrm{~h}$ in THP-1 cells (Fig. 2). In contrast, level of NPR2 was down-regulated. Astonishingly, in human PBMC expression levels of all genes were slightly down-regulated by oxLDL. However, this effect was significant only for NPR3. These effects might be due to different expression profiles of scavenger receptors or Toll-like receptors in PBMC compared to THP-1 cells. In 2010, Levitan and coworkers performed an extensive review on diversity, patterns of recognition, and pathophysiology of oxLDL [60]. They summarized that the effect of oxLDL on inflammatory response is dose dependent. OxLDL in high concentrations leads to inhibition of NF- $\kappa \mathrm{B}$ and consecutively to reduced expression of inflammatory mediators. In accordance, Jovinge et al. showed that oxLDL in concentrations of $>15 \mu \mathrm{g} /$ $\mathrm{ml}$ suppress the expression of TNF- $\alpha$ and IL-1 $\beta$, while lower concentrations of oxLDL increase the level of TNF- $\alpha$ [40]. The abovementioned results are in agreement with our results (oxLDL $=50 \mu \mathrm{g} / \mathrm{ml}$ ), however, the decrease of TNF- $\alpha$ and IL- $1 \beta$ in PBMC in our study was observed only by trend. The study of Jovinge et al. [40] has some similarities to our experiments. Monocytes/Macrophages were isolated in a comparable manner and analysis was also performed after $48 \mathrm{~h}$. In contrast, LDL was oxidized using a higher concentration of CuSO4, but the incubation time was slightly shorter (18h). In addition, expression analysis of inflammatory cytokines was performed by ELISA, not by quantitative PCR. In contrast, Ardans et al. showed that stimulation of human peripheral blood monocytes with $5 \mu \mathrm{g} / \mathrm{ml}$ oxLDL had no impact on PGE2 secretion [61]. However, these measurements were performed by ELISA already after $24 \mathrm{~h}$. Taketa et al. showed that oxLDL $(40 \mu \mathrm{g} / \mathrm{ml})$ increases NF- $\mathrm{k}$ B activity after $24 \mathrm{~h}$. Referring to this, it must be mentioned that this study was carried out using mouse peritoneal macrophages and applied oxLDL had lower TBARS. Furthermore, Terkeltaub et al. showed that stimulation of PBMC with oxLDL $(40 \mu \mathrm{g} / \mathrm{ml})$ leads to an increase of IL-1 $\beta$ secretion after $24 \mathrm{~h}$ [55]. In contrast, secretion of TNF- $\alpha$ was not affected. In accordance to the present study, Mikita et al. [38] showed that IL-1 $\beta$ and TNF- $\alpha$ were slightly increased after stimulating THP- 1 cells with oxLDL $(100 \mu \mathrm{g} / \mathrm{ml}, 72 \mathrm{~h}$ of stimulation). In contrast, in a study by Qiu et al. [62], Il-1 $\beta$, TNF- $\alpha$, and IL- 6 were reduced by oxLDL. Concentration of oxLDL and its degree of oxidation was identical to our study. However, it must be mentioned that measuring time point was at $72 \mathrm{~h}$ and THP- 1 cells used in this experiment were previously transfected with a lentiviral control plasmid. Another study carried out by Terkeltaub et al. revealed no effect of oxLDL $(75 \mu \mathrm{g} / \mathrm{ml})$ on IL- $1 \beta$ expression 


\section{Cellular Physiology Cell Physiol Biochem 2012;30:199-209 \\ and Biochemistry $\begin{array}{ll}\text { DOI: 10.1159/000339044 } & \begin{array}{l}\text { Published online: June 19, 2012 S. Karger AG, Basel } \\ \text { www.karger.com/cpb }\end{array} \\ \begin{array}{l}\text { Bruckmeier/Kuehnl/Culmes/Pelisek/Eckstein: CNP and its Receptors in Human } \\ \text { Monocytes }\end{array}\end{array}$}

already after 24h [55]. In summary, our results are in general in accordance to published studies that are methodological comparable.

\section{Effect of oxLDL and LPS on NPR2-NPR3 ratio}

With respect to oxLDL signal transduction via activation of protein-kinase C (PKC), NPR2 and NPR3 act contrariwise [29]. While NPR2 reduces PKC activity, NPR3 activates PKC by stimulation of phospholipase-C [29]. Thus, the higher the ratio of NPR2/3 expression level, the stronger inhibition of CNP on oxLDL-induced effects should be. NPR2/3-ratio was higher in THP-1 cells at baseline and after 48h (figure 3). Following 24h, NPR2/3-ratio levelled up in both cell types but was inverted after treatment with LPS. Following treatment with oxLDL for 48h, NPR2/3-ratio increased significantly in human monocytes and decreased significantly in THP-1 cells. Thus, oxLDL seems to induce negative feedback with respect to PLC/PKC-pathway in human monocytes. Because intracellular signalling of oxLDL is also by MAPK-pathway [4], oxLDL induced decrease of NPR3 expression in PBMC is counteracting. In contrast, fall of NPR2/3-ratio in THP-1 cells after 48h treatment with oxLDL may suppose a positive feedback mechanism. Finally, the resulting effect of NPR2/3 balance on oxLDL signalling remains unclear. It is to note that the effects of oxLDL are generated by various intracellular pathways, which might be in part influenced by NPR2/3, in part by other synergistic or even antagonistic pathways. Our current data suppose that the NPR2/3-ratio might be important for the influence of CNP on effects induced by oxLDL. Further studies are needed to investigate different intracellular pathways in more details, especially regarding oxLDL stimulation, which leads to complete different behaviour of PBMC and THP-1 cells.

\section{Limitations of this study}

It should be in mind that PBMC are an inhomogeneous cell fraction having some limitations like donor variability, cell viability and influence of other blood cells [34]. Beside monocytes, PBMC consist also of lymphocytes, natural killer cells and others. All these factors have some influence on statistical spread of results. In addition, method of isolation (e.g. centrifugation, adherence to plastic wells) might also have an influence on basic gene expression. Because this method was the same in all experiments, direct comparison of LPS-effects and oxLDL-effects at the same time points is most likely to be valid. In future experiments, one may also use a technique for isolation of "untouched" CD14 ${ }^{\text {pos }}$-monocytes by negative selection. Unfortunately, this method was not available in our laboratory.

\section{Conclusions}

In summary, baseline expression of CNP, NPR2, NPR3, TNF- $\alpha$, IL-1 $\beta$, IL-6, CD14, and CD68 is significantly lower in THP-1 cells compared to human PBMC. Treatment with oxLDLleads to a diverging change in expression levels of the named genes in these cell types. In addition, oxLDL showed an opposite effect on NPR2/3-ratio in PBMC and THP-1 cells. With respect to CNP and its receptors, data gained from THP- 1 cells should be further validated using naive human peripheral blood monocytes. However, THP-1 cells can serve as a negative control for e.g. future signalling pathway studies related to oxLDL effect on CNP system in monocytes/macrophages.

\section{Acknowledgements}

We would like to thank Mrs. Renate Hegenloh for her excellent technical assistance. 


\section{Cellular Physiology Cell Physiol Biochem 2012;30:199-209 \begin{tabular}{ll|l} 
and BiOchemistry & $\begin{array}{l}\text { DOI: 10.1159/000339044 } \\
\text { Published online: June 19, } 2012\end{array}$ & $\begin{array}{l}\text { C 2012 S. Karger AG, Basel } \\
\text { www.karger.com/cpb }\end{array}$ \\
\cline { 2 - 2 }
\end{tabular} Bruckmeier/Kuehnl/Culmes/Pelisek/Eckstein: CNP and its Receptors in Human Monocytes}

\section{References}

1 WHO: Global_burden_disease_DTH6_2008.xls. 2011; Available from: http://www.who.int/research/en/.

2 Hansson GK, Libby P: The immune response in atherosclerosis: a double-edged sword. Nat Rev Immunol 2006;6:508-519.

3 Saha P, Modarai B, Humphries J, Mattock K, Waltham M, Burnand KG, Smith A: The monocyte/macrophage as a therapeutic target in atherosclerosis. Curr Opin Pharmacol 2009;9:109-118.

4 Chisolm GM, 3rd, Chai Y: Regulation of cell growth by oxidized LDL. Free Radic Biol Med 2000;28:16971707.

5 Galkina E, Ley K: Immune and inflammatory mechanisms of atherosclerosis $\left.{ }^{*}\right)$. Annu Rev Immunol 2009;27:165-197.

6 Potter LR, Yoder AR, Flora DR, Antos LK, Dickey DM: Natriuretic peptides: their structures, receptors, physiologic functions and therapeutic applications. Handb Exp Pharmacol 2009;191:341-366.

$7 \quad$ Nishikimi T, Kuwahara K, Nakao K: Current biochemistry, molecular biology, and clinical relevance of natriuretic peptides. J Cardiol 2011; 7:131-140.

8 Woodard GE, Rosado JA: Natriuretic peptides in vascular physiology and pathology. Int Rev Cell Mol Biol 2008;268:59-93.

9 Sudoh T, Minamino N, Kangawa K, Matsuo H: C-type natriuretic peptide (CNP): a new member of natriuretic peptide family identified in porcine brain. Biochem Biophys Res Commun 1990;168:863-870.

10 Inoue K, Naruse K, Yamagami S, Mitani H, Suzuki N, Takei Y: Four functionally distinct C-type natriuretic peptides found in fish reveal evolutionary history of the natriuretic peptide system. Proc Natl Acad Sci USA 2003;100:10079-10084.

11 Pelisek J, Fuchs AT, Kuehnl A, Tian W, Kuhlmann MT, Rolland PH, Mekkaoui C, Gaedtke L, Nikol S. C-type natriuretic peptide for reduction of restenosis: gene transfer is superior over single peptide administration. J Gene Med 2006;8(7):835-844.

12 Kuehnl A, Pelisek J, Tian W, Kuhlmann M, Rolland PH, Mekkaoui C, Fuchs A, Nikol S: C-type natriuretic peptide inhibits constrictive remodeling without compromising re-endothelialization in balloon-dilated renal arteries. J Endovasc Ther 2005;12:171-182.

13 Saha S, Li Y, Lappas G, Anand-Srivastava MB. Activation of natriuretic peptide receptor-C attenuates the enhanced oxidative stress in vascular smooth muscle cells from spontaneously hypertensive rats: implication of Gialpha protein. J Mol Cell Cardiol 2008;44:336-344.

14 Pagel-Langenickel I, Buttgereit J, Bader M, Langenickel TH: Natriuretic peptide receptor B signaling in the cardiovascular system: protection from cardiac hypertrophy. J Mol Med 2007;85:797-810.

15 Bartels CF, Bukulmez H, Padayatti P, Rhee DK, van Ravenswaaij-Arts C, Pauli RM, Mundlos S, Chitayat D, Shih LY, Al-Gazali LI, Kant S, Cole T, Morton J, Cormier-Daire V, Faivre L, Lees M, Kirk J, Mortier GR, Leroy J, Zabel B, Kim CA, Crow Y, Braverman NE, van den Akker F, Warman ML: Mutations in the transmembrane natriuretic peptide receptor NPR-B impair skeletal growth and cause acromesomelic dysplasia, type Maroteaux. Am J Hum Genet 2004;75:27-34.

16 Teixeira CC, Agoston H, Beier F: Nitric oxide, C-type natriuretic peptide and cGMP as regulators of endochondral ossification. Dev Biol 2008;319:171-178.

17 Walther T, Stepan H: C-type natriuretic peptide in reproduction, pregnancy and fetal development. J Endocrinol 2004;180:17-22.

18 Walther T, Stepan H: C-type natriuretic peptide in reproduction, pregnancy and fetal development. J Endocrinol 2004;180: 7-22.

19 Schmidt H, Stonkute A, Juttner R, Koesling D, Friebe A, Rathjen FG: C-type natriuretic peptide (CNP) is a bifurcation factor for sensory neurons. Proc Natl Acad Sci USA 2009;106:16847-16852.

20 Doi K, Ikeda T, Itoh H, Ueyama K, Hosoda K, Ogawa Y, Yamashita J, Chun TH, Inoue M, Masatsugu K, Sawada N, Fukunaga Y, Saito T, Sone M, Yamahara K, Kook H, Komeda M, Ueda M, Nakao K: C-type natriuretic peptide induces redifferentiation of vascular smooth muscle cells with accelerated reendothelialization. Arterioscler Thromb Vasc Biol 2001;21:930-936.

$21 \mathrm{Hu}$ P, Lu L, Hu B, Qin YH: Renal action of C-type natriuretic peptide: advocating the isolated perfused rat kidney model. Saudi J Kidney Dis Transpl 2010;21:613-620.

22 Sabbatini ME, Rodriguez MR, Dabas P, Vatta MS, Bianciotti LG: C-type natriuretic peptide stimulates pancreatic exocrine secretion in the rat: role of vagal afferent and efferent pathways. Eur J Pharmacol 2007;577:192-202. 


\section{Cellular Physiology Cell Physiol Biochem 2012;30:199-209 \begin{tabular}{ll|l} 
and BiOchemistry & $\begin{array}{l}\text { DOI 10.1159/000339044 } \\
\text { Published online: June 19, } 2012\end{array}$ & $\begin{array}{l}\text { C 2012 S. Karger AG, Basel } \\
\text { www.karger.com/cpb }\end{array}$ \\
\cline { 2 - 3 }
\end{tabular} Bruckmeier/Kuehnl/Culmes/Pelisek/Eckstein: CNP and its Receptors in Human Monocytes}

23 Palmer SC, Prickett TC, Espiner EA, Yandle TG, Richards AM: Regional release and clearance of C-type natriuretic peptides in the human circulation and relation to cardiac function. Hypertension 2009;54:612618.

24 Pelisek J, Kuehnl A, Rolland PH, Mekkaoui C, Fuchs A, Walker GF, Ogris M, Wagner E, Nikol S: Functional analysis of genomic DNA, cDNA, and nucleotide sequence of the mature C-type natriuretic peptide gene in vascular cells. Arterioscler Thromb Vasc Biol 2004;24:1646-1651.

25 Federico C: Natriuretic Peptide system and cardiovascular disease. Heart Views 2010;11:10-15.

26 Castro GP, Dussin LH, Wender OB, Barbosa GV, Saadi EK: [Comparative analysis of the flows of left internal thoracic artery grafts dissected in the pedicled versus skeletonized manner for myocardial revascularization surgery]. Arq Bras Cardiol 2005;84:261-266.

27 Sandow SL, Tare M: C-type natriuretic peptide: a new endothelium-derived hyperpolarizing factor? Trends Pharmacol Sci 2007;28(2):61-67.

28 Simon A, Harrington EO, Liu GX, Koren G, Choudhary G: Mechanism of C-type natriuretic peptide-induced endothelial cell hyperpolarization. Am J Physiol Lung Cell Mol Physiol 2009;296(2):L248-256.

29 Anand-Srivastava MB: Natriuretic peptide receptor-C signaling and regulation. Peptides 2005;26:10441059.

30 Kiemer AK, Lehner MD, Hartung T, Vollmar AM: Inhibition of cyclooxygenase-2 by natriuretic peptides. Endocrinology 2002;143:846-852.

31 Hashim S, Li Y, Anand-Srivastava MB: Small cytoplasmic domain peptides of natriuretic peptide receptor-C attenuate cell proliferation through Gialpha protein/MAP kinase/PI3-kinase/AKT pathways. Am J Physiol Heart Circ Physiol 2006;291:H3144-3153.

32 Schulz S: C-type natriuretic peptide and guanylyl cyclase B receptor. Peptides 2005;26:1024-1034.

33 Tsuchiya S, Yamabe M, Yamaguchi Y, Kobayashi Y, Konno T, Tada K: Establishment and characterization of a human acute monocytic leukemia cell line (THP-1). Int J Cancer 1980;26:171-176.

34 Qin Z: The use of THP-1 cells as a model for mimicking the function and regulation of monocytes and macrophages in the vasculature. Atherosclerosis 2011;221:2-11.

35 Li M, Lin J, Wang Z, He S, Ma X, Li D: Oxidized low-density lipoprotein-induced proinflammatory cytokine response in macrophages are suppressed by CD4CD25(+)Foxp3(+) regulatory T cells through downregulating toll like receptor 2-mediated activation of NF-kappaB. Cell Physiol Biochem 2010;25:649656.

36 Shiffman D, Mikita T, Tai JT, Wade DP, Porter JG, Seilhamer JJ, Somogyi R, Liang S, Lawn RM: Large scale gene expression analysis of cholesterol-loaded macrophages. J Biol Chem 2000;275:37324-37332.

37 Whatling C, Bjork H, Gredmark S, Hamsten A, Eriksson P: Effect of macrophage differentiation and exposure to mildly oxidized LDL on the proteolytic repertoire of THP-1 monocytes. J Lipid Res 2004;45:1768-1776.

38 Mikita T, Porter G, Lawn RM, Shiffman D. Oxidized low density lipoprotein exposure alters the transcriptional response of macrophages to inflammatory stimulus. J Biol Chem 2001; 276(49): 45729-39.

39 Xue X, Lai KT, Huang JF, Gu Y, Karlsson L, Fourie A: Anti-inflammatory activity in vitro and in vivo of the protein farnesyltransferase inhibitor tipifarnib. J Pharmacol Exp Ther 2006;317:53-60.

40 Jovinge S, Ares MP, Kallin B, Nilsson J: Human monocytes/macrophages release TNF-alpha in response to Ox-LDL. Arterioscler Thromb Vasc Biol 1996;16:1573-1579.

41 Rinne H: Taschenbuch der Statistik. 4th ed. Frankfurt am Main: Wissenschaftlicher Verlag Harri Deutsch GmbH; 2008.

42 Martens JS, Reiner NE, Herrera-Velit P, Steinbrecher UP: Phosphatidylinositol 3-kinase is involved in the induction of macrophage growth by oxidized low density lipoprotein. J Biol Chem 1998;273:4915-4920.

43 Martens JS, Lougheed M, Gomez-Munoz A, Steinbrecher UP: A modification of apolipoprotein B accounts for most of the induction of macrophage growth by oxidized low density lipoprotein. J Biol Chem 1999;274:10903-10910.

44 Yamamoto K, Ikeda U, Shimada K: Role of mechanical stress in monocytes/macrophages: implications for atherosclerosis. Curr Vasc Pharmacol 2003;1:315-319.

45 Graziani-Bowering GM, Graham JM, Filion LG: A quick, easy and inexpensive method for the isolation of human peripheral blood monocytes. J Immunol Methods 1997;207:157-168.

46 de Carvalho CM, Bonnefont-Rebeix C, Picandet S, Bernaud J, Phothirath P, Chabanne L, Marchal T, Magnol JP, Rigal D: Evaluation of elutriation and magnetic microbead purification of canine monocytes. Vet Immunol Immunopathol 2004;101:171-178. 


\section{Cellular Physiology Cell Physiol Biochem 2012;30:199-209

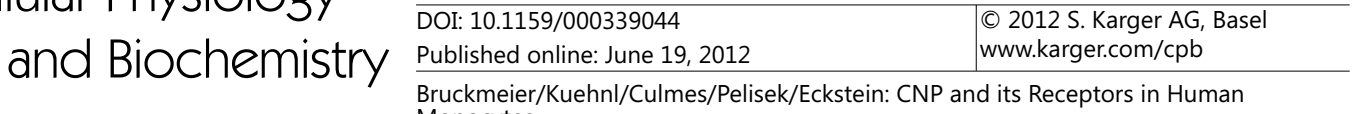 Monocytes}

47 Lund PK, Joo GB, Westvik AB, Ovstebo R, Kierulf P: Isolation of monocytes from whole blood by density gradient centrifugation and counter-current elutriation followed by cryopreservation: six years' experience. Scand J Clin Lab Invest 2000;60:357-365.

48 Sugiyama S, Kugiyama K, Matsumura T, Suga S, Itoh H, Nakao K, Yasue H: Lipoproteins regulate C-type natriuretic peptide secretion from cultured vascular endothelial cells. Arteriosclerosis, thrombosis, and vascular biology 1995;15:1968-1974.

49 Sellitti DF, Koles N, Mendonca MC: Regulation of C-type natriuretic peptide expression. Peptides 2011;32:1964-1971.

50 Vollmar AM, Schulz R: Expression and differential regulation of natriuretic peptides in mouse macrophages. J Clin Invest 1995;95:2442-2450.

51 Kubo A, Isumi Y, Ishizaka Y, Tomoda Y, Kangawa K, Dohi K, Matsuo H, Minamino N: C-type natriuretic peptide is synthesized and secreted from leukemia cell lines, peripheral blood cells, and peritoneal macrophages. Exp Hematol 2001;29:609-615.

52 Suga S, Itoh H, Komatsu Y, Ogawa Y, Hama N, Yoshimasa T, Nakao K: Cytokine-induced C-type natriuretic peptide (CNP) secretion from vascular endothelial cells--evidence for CNP as a novel autocrine/paracrine regulator from endothelial cells. Endocrinology 1993;133:3038-3041.

53 Miyoshi M, Watanabe T: Role of anterior hypothalamic natriuretic peptide in lipopolysaccharide-induced fever in rats. Eur J Appl Physiol 2010;109:49-57.

54 Bas S, Neff L, Vuillet M, Spenato U, Seya T, Matsumoto M, Gabay C: The proinflammatory cytokine response to Chlamydia trachomatis elementary bodies in human macrophages is partly mediated by a lipoprotein, the macrophage infectivity potentiator, through TLR2/TLR1/TLR6 and CD14. J Immunol 2008;180:11581168.

55 Terkeltaub R, Banka CL, Solan J, Santoro D, Brand K, Curtiss LK: Oxidized LDL induces monocytic cell expression of interleukin-8, a chemokine with T-lymphocyte chemotactic activity. Arterioscler Thromb 1994;14:47-53.

56 Ahmadzadeh E, Zarkesh-Esfahani H, Roghanian R, Akbar FN: Comparison of Helicobacter pylori and Escherichia coli in induction of TNF-alpha mRNA from human peripheral blood mononuclear cells. Indian J Med Microbiol 2010;28:233-237.

57 Caruso R, Stolfi C, Sarra M, Rizzo A, Fantini MC, Pallone F, MacDonald TT, Monteleone G: Inhibition of monocyte-derived inflammatory cytokines by IL-25 occurs via p38 Map kinase-dependent induction of Socs-3. Blood 2009;113:3512-3519.

58 Molnarfi N, Gruaz L, Dayer JM, Burger D: Opposite regulation of IL-1beta and secreted IL-1 receptor antagonist production by phosphatidylinositide-3 kinases in human monocytes activated by lipopolysaccharides or contact with T cells. J Immunol 2007;178:446-454.

59 Perez-Perez GI, Shepherd VL, Morrow JD, Blaser MJ: Activation of human THP-1 cells and rat bone marrowderived macrophages by Helicobacter pylori lipopolysaccharide. Infect Immun 1995;63(4):1183-1187.

60 Levitan I, Volkov S, Subbaiah PV. Oxidized LDL: diversity, patterns of recognition, and pathophysiology. Antioxid Redox Signal 2010;13:39-75.

61 Ardans JA, Economou AP, Martinson JM Jr., Zhou M, Wahl LM: Oxidized low-density and high-density lipoproteins regulate the production of matrix metalloproteinase- 1 and -9 by activated monocytes. J Leukoc Biol 2002;71:1012-1018.

62 Qiu G, Ho AC, Yu W, Hill JS: Suppression of endothelial or lipoprotein lipase in THP-1 macrophages attenuates proinflammatory cytokine secretion. J Lipid Res 2007;48:385-394. 